\title{
FSN-NU 0009 \\ HAEMATOLOGICAL PROFILE OF BLOOD OF AFRICAN CATFISH (Clarias gariepinus, Burchell 1822) FED SUNFLOWER AND SESAME MEAL BASED DIETS
}

\author{
${ }^{1}$ FAGBENRO O. A., ${ }^{1}$ E. O. ADEPARUSI, ${ }^{2}$ W. A. JIMOH \\ ${ }^{1}$ Department of Fisheries and Aquaculture Technology, Federal University of Technology, Akure, Ondo State. \\ ${ }^{2}$ Fisheries and Aquaculture Unit, Department of Biological Sciences, Crescent University, Abeokuta, Ogun State
}

Copyright 2010, Fisheries Society of Nigeria.

This paper was prepared for presentation at the 25th Annual International Conference and Exhibition in Administrative Staff College of Nigeria (ASCON), Topo-Badagry, Lagos, Nigeria, 25th - 29th October, 2010.

This paper was selected for presentation by an FISON Program Committee following review of information contained in an abstract submitted by the author(s). Contents of the paper, as presented, have not been reviewed by the Fisheries Society of Nigeria and are subject to correction by the author(s). The material, as presented, does not necessarily reflect any position of the Fisheries Society of Nigeria its officers, or menters. Papers prosented at FISON motings or the Fisheries Society of Nigeria. Electronic reproduction, distribution, the Fisheries society the cor the consent of the Fisheries Society of Nigeria is prohibited. Permission to reproduce in print is restricted to an abstract of not more than 300 words, ilustrations may not be copied. The abstract must contain conspicuous acknowledgement of where and by whom the paper was presented. Write Librarian, Fisheries Society of Nigeria (FISON), P. O. Box 2607 Apapa, Lagos.

\section{ABSTRACT}

The effect of substituting soybean meal with raw sunflower and sesame seed meal was evaluated using haematological indices of Clarias gariepinus fed the diets containing sunflower and sesame seed meal. Seven isonitrogeneous and isocaloric diets containing sunflower and sesame seed meal replacing soybean meal at a rate of 15, 30 and $45 \%$ were prepared. A diet without replacement of soybean meal served as control. The result of fish fed test diets showed significant $(P<0.05)$ difference over the fish fed control diet with respect to $P C V$ and mean corpuscular volume (MCV). Fish fed control diet had the lowest $H_{b}, P C V, W B C$, RBC, MCV, MCHC, ESr. There was no significant difference $(P>0.05)$ in the fish fed control diet and test diets with respect to $\mathrm{MCH}, \mathrm{MCHC}, \mathrm{ESr}$, Neutrophil, Monocytes, Eusinophils and Lymphocytes. Hence it can be concluded that the haemotological parameter of Clarias gariepinus is not significantly $(P>0.05)$ changed with increase dietary inclusion of raw sunflower and sesame seed meal.

\section{INTRODUCTION}

Catfish farming and indeed aquaculture offer strong potential for growth to meet the natural fish demand thereby reducing importation, provides employment, alleviates poverty and helps to meet the millennium development goals (William et al., 2007). There are many culturable catfish species which are but not limited to Clarias gariepinus, C. anguillaris, Heterobranchus bidorsalis, $H$. longifilis, C. isheriensis, C. submarginatus, Chrysichthys nigrodigititatus, Bagrus spp., Synodontis Sp. But Clarias gariepinus is the most cultured fish in Nigeria and indeed Africa (Garibaldi, 1996). Its hardness, omnivory, ability to understand adverse condition, high fecundity and mass artificial seed technique also ease its culture (Haylor, 1992, Hecht et al., 1996). Ichythyohaematological investigation serves mainly for diagnostic purpose; apart from this main purpose, it is also used to assess suitability of feeds and feed mixture pellets, to evaluate the effect of stress situation etc. (Svobodova et al., 1991). As with all animal production, disease is considerable constraint in production, development and expansion in the aquaculture industry. There can be a wide variation in the quality of diet received by farmed fish. Factors include the poor availability of suitable constituents, poor formulation and processing, lack of knowledge and understanding of dietary requirement or in appropriate storage ( Southgate, 1993). Soybean meal (SBM) is currently the most commonly used plant protein source in fish feed (El-Sayyed, 1999). However, other plant protein sources which are less expensive would be 
beneficial in reducing feed cost when made to replace soybean meal (Barros et al., 2002).

Blood analysis is a valuable means of evaluating the physiological condition of cultured fish with respect to determining the effect of diets and other stress factors on fish health. Changes in haematology of fish in response to stressing agents are indicators of the stressful stage of fish, producing useful information to curb any unfavourable condition that may affect the fish health. (Bello-Olusoji et al., 2006). Adeparusi and Ajayi (2004) reported that analysis of blood is an important factors that could be considered in fish feed assessment. Hence, this study investigates the haematological characteristic of Clarias gariepinus fed with sesame and sunflower meal based diets replacing soybean meal based diet. The use of haematological values as indices of diagnosing diseases and stress induced condition as well as for feed assessment is well documented (Fagbenro et al., 1993; Adeparusi and Ajayi, 2004; George et al., 2007; Yue and Zhou, 2008;Akintayo et al., 2008).

\section{MATERIALS AND METHODS} Sources and Processing of Ingredients

The dehulled seeds of sunflower and sesame were obtained from a farm in Kebbi State, Nigeria. They were ground in a hammer mill and the oil therein was removed using the pressure generated from locally made screw press (cassava-presser type). The cakes therefore were analyzed for their proximate composition (AOAC 1990). Fish meal, soybean meal and other feedstuffs obtained from commercial sources in Nigeria were separately milled screened to fine particles size and triplicate samples were analyzed for their proximate composition (AOAC, 1990). Based on the nutrient composition of the protein feed stuff (Table 1), a control diet and six test diets $(40 \%$ crude Protein, $12 \%$ crude Lipid, 18 MJ energy) were formulated. The control diets contained soybean meal, providing $50 \%$ of the total protein. Three of the test diets contained sunflower meal protein at a replacement levels of 15, 30 and $45 \%$ for the soybean meal to serve as test diets $\mathrm{RSF}_{15}, \mathrm{RSF}_{30}$, and $\mathrm{RSF}_{45}$ respectively while the other three contained sesame meal protein at the same replacement levels for the soybean meal to serve as test diets $\mathrm{RSM}_{15}, \mathrm{RSM}_{30}$, and $\mathrm{RSM}_{45}$ respectively (Table 2 ). The feedstuffs were blended, moistened, steam pelleted and oven dried for $24 \mathrm{hrs}$. 
Table 1: Proximate Composition of Carcass of Protein Feed Ingredients

\begin{tabular}{llllll}
\hline Parameter & Fishmeal & Soybean Meal & Sunflower Meal & Sesame Meal & Corn Meal \\
\hline Moisture & 7.59 & 8.92 & 9.48 & 8.39 & 9.21 \\
Crude Protein & 69.76 & 42.81 & 40.01 & 42.21 & 15.89 \\
Crude Lipid & 8.82 & 18.56 & 20.28 & 5.48 & 1.49 \\
Crude Fibre & - & 5.63 & 12.80 & 7.27 & 29.78 \\
Ash & 13,83 & 6.01 & 11.54 & 20.73 & 3.81 \\
NFE & - & 18.07 & & & 46.82 \\
\hline
\end{tabular}

Table 2: Gross and Proximate Composition (G/100g Dry Matter) of Experimental Diets fed to Clarias gariepinus at Varying Replacement Levels of Raw Samples of Sunflower and Sesame Seedmeal Based Diets.

\begin{tabular}{|c|c|c|c|c|c|c|c|c|}
\hline \multirow[b]{2}{*}{ Ingredients } & \multicolumn{2}{|c|}{ Experimental Diets } & \multirow[b]{2}{*}{$\mathrm{RSF}_{30}$} & \multirow[b]{2}{*}{$\mathrm{RSF}_{45}$} & \multirow[b]{2}{*}{$\mathrm{RSM}_{15}$} & \multirow[b]{2}{*}{$\mathrm{RSM}_{30}$} & \multirow{2}{*}{\multicolumn{2}{|c|}{$\mathrm{RSM}_{45}$}} \\
\hline & CTR & $\mathrm{RSF}_{15}$ & & & & & & \\
\hline Fishmeal & 27.24 & 27.24 & 27.24 & 27.24 & 27.24 & 27.24 & & 27.24 \\
\hline Soybean meal & 46.71 & 39.71 & 32.70 & 25.70 & 39.71 & 32.70 & & 25.70 \\
\hline Raw samples & - & 7.48 & 14.96 & 22.44 & 7.08 & 14.16 & & 21.25 \\
\hline Corn meal & 11.25 & 11.25 & 11.25 & 11.25 & 11.25 & 11.25 & & 11.25 \\
\hline Fish oil & 5.09 & 5.09 & 5.09 & 5.09 & 5.09 & 5.09 & & 5.09 \\
\hline Vita/Min & 5.00 & 5.00 & 5.00 & 5.00 & 5.00 & 5.00 & & 5.00 \\
\hline \multicolumn{9}{|l|}{ Premix } \\
\hline Starch & 4.76 & 4.22 & 3.76 & 3.28 & 4.63 & 4.26 & & 4.17 \\
\hline Total & 100 & 100 & 100 & 100 & 100 & 100 & & 100 \\
\hline \multicolumn{9}{|c|}{ Proximate Composition } \\
\hline Moisture & $9.17 \pm .15^{\mathrm{b}}$ & $9.67 \pm .72^{\mathrm{a}}$ & $9.36 \pm .46^{\mathrm{ab}}$ & $9.57 \pm .09^{\mathrm{ab}}$ & $9.39 \pm .19^{\mathrm{ab}}$ & $\begin{array}{l}9.43 \\
.26^{\mathrm{ab}}\end{array}$ & \pm & $9.37 \pm .15^{\mathrm{ab}}$ \\
\hline $\begin{array}{l}\text { Crude } \\
\text { protein }\end{array}$ & $40.60 \pm .72$ & $40.47 \pm .46$ & $\begin{array}{ll}40.28 & \pm \\
.87 & \end{array}$ & $\begin{array}{l}40.18 \quad \pm \\
.28\end{array}$ & $40.48 \pm .61$ & $\begin{array}{l}40.42 \\
.36\end{array}$ & \pm & $40.24 \pm .38$ \\
\hline Crude lipid & $11.74 \pm .04^{\mathrm{c}}$ & $12.18 \pm .12^{\mathrm{ab}}$ & $12.28 \pm .05^{\mathrm{a}}$ & $12.32 \pm .05^{\mathrm{a}}$ & $11.93 \pm .12^{\mathrm{bc}}$ & $\begin{array}{l}12.33 \\
.06^{\mathrm{a}}\end{array}$ & & $12.46 \pm .35^{\mathrm{a}}$ \\
\hline Crude fibre & $5.84 \pm .10^{\mathrm{b}}$ & $5.84 \pm .08^{b}$ & $6.44 \pm .29^{\mathrm{a}}$ & $6.44 \pm .28^{\mathrm{a}}$ & $5.53 \pm .28^{\mathrm{b}}$ & $\begin{array}{l}5.90 \\
\pm .04^{\mathrm{b}}\end{array}$ & & $5.87 \pm .22^{\mathrm{b}}$ \\
\hline Ash & $9.35 \pm .10^{\mathrm{a}}$ & $8.71 \pm .24^{\mathrm{bc}}$ & $8.80 \pm .11^{\mathrm{bc}}$ & $9.04 \pm .47^{\mathrm{ab}}$ & $8.91 \pm .13^{\mathrm{abc}}$ & $\begin{array}{l}8.81 \\
.11^{\mathrm{bc}}\end{array}$ & \pm & $8.51 \pm .27^{c}$ \\
\hline NFE & $23.13 \pm .74$ & $23.42 \pm .39$ & $\begin{array}{l}23.05 \\
.75 \\
\end{array}$ & $\begin{array}{l}22.46 \\
.13 \\
\end{array}$ & $23.76 \pm .93$ & $\begin{array}{l}22.92 \\
.26 \\
\end{array}$ & \pm & $23.55 \pm .94$ \\
\hline
\end{tabular}

\section{Culture Condition}

Clarias gariepinus fingerlings were acclimated to experimental condition for 7 days prior to the feeding trial. Groups of 15 catfish fingerlings $(3.38 \pm 0.015 \mathrm{~g})$ were stocked into aquaria comprising 60 litrecapacity rectangular plastic tanks. Each diet was fed to the catfish in triplicate tanks twice daily $(09.00 \mathrm{~h}, 16.00 \mathrm{~h})$ at $5 \%$ body weight for 70 days. Fish was removed from each tank every 14 days and batch-weighed and the amount of feed was adjusted accordingly. Eight catfish and 6 catfish per treatment were respectively sacrificed at the beginning and end of the feeding trial respectively

\section{HAEMATOLOGICAL STUDIES}

The blood analyses were determined according to the method described by Svobodova et al., (1991). The following were done.

\section{Blood Analysis}

5-10ml blood samples were collected from cardiac puncture using $2 \mathrm{ml}$ disposable heparinised syringe treated with EDTA as anti-coagulant.

\section{Blood Cell Count}

Haemocytometer was used in blood cell count. The blood diluting fluid was prepared as described by Svobodova et al., (1991). The blood cells were counted on the counting chamber of haemocytometer with the aid of compound microscope. 
$\mathrm{RBC}=$ No of cells counted $\times 3 \times 10 \times 200$ $\left(10^{6} \mathrm{~mm}^{3}\right)$

WBC $=$ no of cells counted $\times 0 \times 25 \times 10 \times$ $20\left(10^{4} \mathrm{~mm}^{3}\right)$

\section{Haemoglobin Estimation}

Haemoblobinometer was used for haemoglobin estimation based on acid haematin method (SAHLI)

Haemoglobin =

Value obtained x $17.2 \mathrm{mg} / 100 \mathrm{ml}$ 100

\section{Packed Cell Volume}

The packed cell volume was measured after placing sealed microhaematocrit tube in a centrifuge at $10,500 \mathrm{rpm}$ using microhaematocrit reader and expressed as percentage.

\section{Erythrocyte Sedimentation Rate (ESR)}

ESR was determined the procedures of Svobodava et al (1991). The volume of ESR with the given time interval is the difference between $100 \%$ and the percentage part presented by the corpusde volume Mean Corpuscular Volume (MCV) was calculated from the haematocrit value (PCV, \% and the Erythrocyte count $\left(\mathrm{Er} \mathrm{mm}^{3}\right)$

$$
\operatorname{MCV}\left(\mu^{3}\right)=\operatorname{PCV} \times \frac{10}{\operatorname{Er}}
$$

Mean Corpuscular

Concentration (MCHC).

This was obtained using the formula

\section{Mean Corpuscular Haemoglobin (MCH)}

This was expressed in picogrammes $(\rho g)$

$$
\mathrm{MCH}(\mathrm{pg})=\frac{\mathrm{Hb}}{\mathrm{Er}} \times 10^{2}
$$

\section{Statistical Analysis}

Data obtained from the experiment was expressed in mean \pm SD and it was subjected to one way Analysis of Variance (ANOVA) using SPSS 16.0 version. Where the ANOVA reveals significant difference $(\mathrm{P}<0.05)$ Duncan multiple range test was used to compare differences among individual treatment means.

\section{RESULTS AND DISCUSSION}

The summary of comparison of haematological parameters of Clarias gariepinus fed sunflower and sesame meal based diets replacing soybean meal at different levels is presented in Table 4.

Table 4:HAEMATOLOGICAL PROFILE OF BLOOD OF Clarias gariepinus FED RAW SUNFLOWER AND SESAME MEAL

\begin{tabular}{|c|c|c|c|c|c|c|c|}
\hline \multirow[b]{2}{*}{ Parameters } & \multicolumn{7}{|c|}{ Experimental Diets } \\
\hline & CTR & $\mathrm{RSF}_{15}$ & $\mathbf{R S F}_{\mathbf{3 0}}$ & $\mathrm{RSF}_{45}$ & $\mathbf{R S M}_{15}$ & $\mathbf{R S M}_{30}$ & $\mathrm{RSM}_{45}$ \\
\hline $\mathrm{Hb}$ & $4.7 \pm .57$ & $9.55 \pm 2.05$ & $10.7 \pm .85$ & $10.75 \pm .35$ & $10.85 \pm 4.88$ & $7.65 \pm 4.31$ & $5.4 \pm .99$ \\
\hline PCV & $14 \pm 1.42^{b}$ & $28.5 \pm 6.36^{\mathrm{ab}}$ & $32 \pm 2.82^{\mathrm{ab}}$ & $34.75 \pm 1.34^{\mathrm{a}}$ & $\underset{\mathrm{ab}}{32.5} \pm 14.84$ & $\begin{array}{l}23.00 \pm \\
12.72^{\mathrm{ab}}\end{array}$ & $16.00 \pm 2.83^{\mathrm{ab}}$ \\
\hline WBC & $3600 \pm 707.10$ & $\begin{array}{l}6050 \pm \\
636.40\end{array}$ & $\begin{array}{l}6000 \pm \\
1697.06\end{array}$ & $6075 \pm 388.91$ & $\begin{array}{l}6600 \pm \\
1697.06\end{array}$ & $\begin{array}{l}4850 \pm \\
2050.61\end{array}$ & $3800 \pm 141.42$ \\
\hline RBC & $1.85 \pm .21$ & $3.35 \pm .78$ & $3.7 \pm .42$ & $3.95 \pm .35$ & $3.90 \pm 1.84$ & $2.78 \pm 1.31$ & $2.05 \pm .21$ \\
\hline МСНC & $33.5 \pm .71$ & $33.5 \pm .28$ & $33.4 \pm .28$ & $33.45 \pm .35$ & $33.40 \pm .28$ & $33.10 \pm .42$ & $33.65 \pm .21$ \\
\hline MCV & $75.70 \pm .99^{b}$ & $85.15 \pm .78^{\mathrm{ab}}$ & $86.60 \pm 2.26^{\mathrm{a}}$ & $83.50 \pm 4.24^{\mathrm{ab}}$ & $83.65 \pm 1.34^{\mathrm{ab}}$ & $81.15 \pm 7.57^{\mathrm{ab}}$ & $77.75 \pm 5.73^{\mathrm{ab}}$ \\
\hline MCH & $25.4 \pm .14$ & $28.55 \pm .50$ & $29.00 \pm .99$ & $27.30 \pm 1.56$ & $28.00 \pm .71$ & $26.9 \pm 2.83$ & $26.2 \pm 2.12$ \\
\hline ESR & $4.50 \pm .42$ & $4.55 \pm 1.76$ & $4.60 \pm .42$ & $4.65 \pm .92$ & $4.55 \pm .92$ & $4.60 \pm .71$ & $4.75 \pm .78$ \\
\hline Neutrophils & $49.00 \pm 1.41$ & $\begin{array}{l}59.00 \quad \pm \\
11.31\end{array}$ & $63.50 \pm 2.12$ & $64.45 \pm 5.16$ & $64.50 \pm 6.36$ & $65.50 \pm 12.02$ & $62.00 \pm 14.14$ \\
\hline Lymphocytes & 50.00 & $41 \pm 11.31$ & $35.50 \pm 3.54$ & $32.30 \pm 3.11$ & $35 \pm 7.07$ & $33 \pm 11.31$ & $38 \pm 14.14$ \\
\hline Monocytes & $1 \pm 1.41$ & ND & ND & ND & $.50 \pm .71$ & $1.5 \pm .71$ & ND \\
\hline Eosinophils & ND & ND & $1 \pm 1.41$ & $1 \pm .71$ & ND & ND & ND \\
\hline HIS & $1.76 \pm 0.00$ & $1.81 \pm 0.025$ & $1.81 \pm 0.08$ & $1.74 \pm 0.08$ & $1.82 \pm 0.03$ & $1.80 \pm 0.57$ & $1.77 \pm 0.32$ \\
\hline
\end{tabular}
BASED DIETS. 
The Erythrocyte count (Er) ranges between 10.85 in fish fed $\mathrm{RSM}_{15}$ to 4.7 in fish fed diet CTR. Er increases with increment in levels of sunflower inclusion and decreases with level of sesame seed meal inclusion. A measurable increase in the haematological parameter observed in the fish fed test diets with respect to fish fed control diets was also observed by Akintayo et al., 2008 who fed the toasted sunflower seed meal to Clarias gariepinus and Yue and Zhou, 2008 who fed cotton seed meal to juvenile hybrid Tilapia, Barros et al., (2002) for channel catfish and El-Saidy and Gaber (2004) for Nile Tilapia. Although, the result trend deviates from the trend reported by Adeparusi and Ajayi ( 2004), who fed Lima bean to Orechromis niloticus. Other researchers who have also reported a decrease in haemocrit and haemoglobin with increase level of ingredients are Blom et al., 2001, Dabrowski et al., 2001, Richard et al., 2003. However there was no significant $(\mathrm{P}>0.05)$ difference in the $\mathrm{Er}$ of fish fed control diet and the fish fed test diets. The Leucocytes counts also ranges between 6.6 x $10^{6} \mathrm{~mm}^{3}$ in fish fed diet $\mathrm{RSM}_{15}$ and $3.6 \mathrm{x}$ $10^{6} \mathrm{~mm}^{3}$ in fish fed diet CTR. Same pattern as recorded for Er was observed for WBC. There was no significant $(\mathrm{P}>0.05)$ difference in fish fed control diet and fish fed test diets with respect to $\mathrm{MCH}$, MCHC, ESr. However significant $(\mathrm{P}<0.05)$ variation existed in the packed cell volume (PCV) and mean corpuscular volume (MCV) of fish fed the control diets and other test diets. The highest PCV was obtained in the blood of fish fed diet $\mathrm{RSF}_{45}$ while the lowest PCV was obtained in the fish fed diet CTR. However there was no significant difference $(\mathrm{P}>0.05)$ in the $\mathrm{PCV}$ of the blood of fish fed diets $\mathrm{RSF}_{15} \mathrm{RSF}_{30}$, $\mathrm{RSF}_{45}, \mathrm{RSM}_{15}, \mathrm{RSM}_{30}$, and $\mathrm{RSM}_{45}$. The highest MCV was obtained in the blood of fish fed $\mathrm{RSF}_{30}$ while the lowest was in the fish fed diet CTR. There was no significant $(\mathrm{P}>0.05)$ variation in the MCV of fish fed other test diets apart from $\mathrm{RSM}_{30}$. There was no significant $(\mathrm{P}>0.05)$ difference in the Leucocytes, Eusinophils, Monocytes and Lymphocytes of fish fed control diets and other test diets. Akinwade et al., 2004 opined that a measurable increase in white blood count of fish or any animal is a function of immunity and animals' resistance to some vulnerable illness or disease. This increase might indicate that the fish under study had high immunity or resistance to disease. George et al. (2007) observed that when $50 \%$ fish meal was replaced by soybean meal in the diet for Clarias gariepinus, there was increase in PCV, $\mathrm{HB}$, and $\mathrm{RBC}$ of the fish fed the diet. High value of Erythrocyte count recorded in this study was also observed by Fagbenro et al., 1993, and Akintayo et al., 2008 which indicates high oxygen absorption and transportation capacity of the cells of the fish under study. Hecht et al., 1996 reported the hardiness of Clarias gariepinus to be due to the presence of aborescent air-breathing organ. The decrease in haematological parameter with increasing level of incorporation of sesame meal might not be unconnected to the presence of tannin and phytate present in the seed meal. Wedemeryer and Yasutake, 1981 reported that blood infection might reduce haematocrit value and erythrocyte count. The result agreed with the observation of Blom et al., 2001, Dabrowski et al., 2001, Richard et al., 2003. But the presence of these antinutrients was not to a level to induce pathological changes in the fish.Thus it can be concluded that not much stress is placed on the health of Clarias gariepinus fed $\mathrm{RSM}_{45}$ and sesame seed meal replacing soybean meal at $\mathrm{RSM}_{15}, \mathrm{RSM}_{30}$ and $\mathrm{RSM}_{45}$.

\section{REFERENCES}

Akintayo I.A., Obasa S.O., Alegbeleyo W.O. and Bangbose A.N (2008). Evaluation of toasted sunflower (Helianthus annus) seed meal in the diets of African catfish (Clarias gariepinus) fingerling. Livestock 
Research for Rural Development 20(10) 28-46.

Akinwande A.A., Moody F.O., Sogbesan O.A., Ugwumba A.A.A. and Ovie S.O (2004). Haematological reponse of Heterobranchus longifilis fed varying dietary protein levels. Proceeding of the $19^{\text {th }}$ annual conference of the Fisheries Society of Nigeria, Ilorin, $29^{\text {th }}$ Nov $-3^{\text {rd }}$ December 2004715 $718 \mathrm{pp}$.

AOAC (1990). Official methods of analysis (K. Helrich ed.) $15^{\text {th }}$ edition vol.1. Association of Official Analysis Chemists (AOAC) Arlington, VA.

Adeparusi E.O. and Ajayi A.D. (2004). Haematological characteristics of Nile Tilapia Oreochromis niloticus fed different Processed Lima bean (Phaseolus lunatus L) diets PP 131 $-137$.

Blom. J.H., Lee K.J. Richard J., Dabrowski K., Ottobre J. (2001). Reproductive efficiency and maternal offspring transfer of gossypol in rainbow trout (Oncorhynchus mykiss) fed diets containing cottonseed meal J. Anim Sci. 79, 1533 - 1539.

Barros M.M., Lim e. Klesius P.H (2002). Effect of soybean replacement by cottonseed meal and iron supplementation on growth, immune response and resistance of channel catfish (Ictalurus punctatus) to Edwarsiella ictaluri challenge. Aquaculture 207, 263 279.

Bello-Olusoji O.A., Omoare V.Y and Nwana L.C. (2006). Comparative Studies on the haematological characteristics of pond-cultured and wild tilapia (Oreochromis niloticus) Linnaeus, 1857. Nigerian Journal of Forestry Vol. 36 No.2 pp $134-141$.

Dabrowski K., Lee K.J., Richard J. Geresko A., Blom J.H; Ottobre
J.S., (2001). Gossypol Isomers bind specifically to blood plasma proteins and spermatozoa of rainbow trout fed diets containing cottonseed meal. Biochem. Biophys. Acta 1525, $37-42$.

El-saidy D.M.S.D., Gaber M.M.A. (2004). Use of cottonseed meal supplemented with iron for detoxication of gossypol as a replacement of fish meal in Nile Tilapia, Oreochromis niloticus (L.) diets Aquac. Res. 35, 859-869.

El-sayed A. - F.M., (1999). Alternative dietary protein sources for farmed tilapia - Oreochromis species Aquaculture 179, 149 - 168.

Fagbenro O.A., Adedire C.O, Owoseeni E.A and Ayotunde E.O. (1993). Studies on the biology and aquaculture potential of feral catfish Heterobranchus bidorsalis (Geoffrey St. Hillare 1809) (Clariidae)

Fagbenro O. A.; Adedire C. O., Owoseeni E.A., and Ayotunde E. O., (1993): Studies on the biology and aquaculture potential of feral catfish Heterobranchus bidorsalis (Geoffroy St. Hilaire 1809) (Clariidae). Tropical Zoology. 6:67-79

George F.O.A., Obasa S.O. and Otubusin S.O. 2007. Growth response and carcass quality of African Catfish (Clarias gariepinus, Burchell, 1822) fed multi-enzymesupplemented soybean meal diets. Appl. Trop. Agric. Vol. 12 no 1 and 2 pp $51-59$.

Garibaldi L. (1996): List of animal species used in aquaculture. FAO Fisheries Circular No. 914.

Haylor G.S. (1992): Some aspects of the biology and culture of the African Catfish Clarias gariepinus with particular reference to developing countries. In recent advances vol. IV. R.J. Robert, J.F Muir (Eds) Blackwell Publication. 
Hecht T.I., Oeilerman, L and Verheust L. 1996. Perspective on Clariid catfish culture in Africa. Aquatic Living Resources 9: $197-206$.

Richard J., Lee K, -J, Czesny S., Ciereszko A., Dabrowski K. 2003. Effect of feeding cottonseed meal contaning diets to broodstock rainbow trout and their impact on the growth of their progenies. Aquaculture 227, $77-87$.

Svobodova Z., Pravda D. and Palackova J. 1991. Unified methods of Haematological Examination of Fish. Research Institute of Fish culture and Hydrobiology, Vodnany,Czecho Slivakia 31 pp

Southgate P. 1993. Disease in Aquaculture for Veterinarians. Fish Husbandry and Medicine. Lydia Brown (Ed.). Pergamon Press. New York pp 91 $-129$

Wedemeyer G.A. and Yasutake W.T. (1981). Clinical methods for assessment of the effect of environmental stress on fish health. U.S. Tech. paper. US Fish and Wild. Serv. 89: 1 - 18 Wash D.C.

Williams B.B., Olaosebikan B.D., Adeleke A. and Fagbenro O.A. (2007). Status of African catfish farming in Nigeria. Proceeding of a workshop on the Development of Genetic Improvement Program for African Catfish Clariasgariepinus 5-9 November,2007, Raul W.P. and Nguyan H.N. (eds) pp 49-56.

Yue $Y_{,}-\mathrm{R}$ and Zhou $\mathrm{Q}_{1}-\mathrm{C} 2008$. Effect of replacing soybean meal with cotton seed meal on growth, feed utilisation and haematological indexes for juvenile hybrid tilapia Oreochromis niloticus x O.aureus Aquaculture $284-185-189$. 